\title{
Utaretulehdusbakteerit tietokantaan ja apuvälineeksi utareterveyden jalostuksessa
}

\author{
Minna Koivula, Esa Mäntysaari ja Enyew Negussie \\ MTT, Kotieläintuotannon tutkimus, Eläinjalostus,31600 Jokioinen, etunimi.sukunimi@mtt.fi
}

\begin{abstract}
Johdanto
Naudanjalostusohjelmissa on Pohjoismaissa parin viime vuosikymmenen ajan kiinnitetty yhä enemmän huomiota lehmien utareterveyteen (katsaus: Heringstad ym. 2000). Utaretulehdus eli mastiitti on yhä tärkein tuotantoeläinten sairauksista aiheuttaen suurimmat tulomenetykset koko maidontuotantosektorille. Pari vuotta sitten tehdyn laskelman mukaan utaretulehdus aiheuttaa tiloille vuosittain jopa yli 85 miljoonan euron tappiot. Hoitotilastojen mukaan arviolta joka kolmas lehmä saa lypsykauden aikana antibioottihoidon ja eläinlääkärien hoitomerkinnöistä noin kolmannes aiheutuu äkillisestä utaretulehduksesta. Kustannuksien vähentämiseksi sekä eläinten hyvinvoinnin ja tuotannon laadun parantamiseksi on myös lypsykarjan jalostusvalintaa suunnattu vastustuskykyisemmän eläinaineksen kehittämiseen.

Utareen puolustusmekanismien aktivoituminen näkyy soluvälitteisen immuunivasteen aiheuttamana korkeana somaattisten solujen lukumääränä (SCC). Bakteeri-infektiossa veren valkosolut tarttuvat utareen epiteeliin ja siirtyvät epiteelin läpi verenkierrosta utareeseen (esim. Persson ym. 1993, Harmon 1994). Tämän seurauksena solujen määrä kasvaa muutamissa tunneissa jopa tuhatkertaiseksi ja samalla myös maidon solukoostumus muuttuu. Ellei tulehdus jää krooniseksi, soluluku palaa yleensä nopeasti normaalille tasolle. Soluluvun kohoaminen on siis utareen tärkein puolustusmekanismi ja osoittaa eläimen kyvyn puolustautua patogeenejä vastaan. Solulukua onkin yleisesti käytetty jalostusarvostelussa utareterveysindikaattorina.
\end{abstract}

\section{Stafylokokit tärkeimpiä utare tulehdusten aiheuttajia}

Lääketieteellisesti utaretulehduksella tarkoitetaan utarekudoksessa esiintyvää tulehdusta, joka on seurausta joko kudosvauriosta tai mikrobin tai toksiinin tunkeutumisesta utarekudokseen. Mastiittia aiheuttavat bakteerit voidaan karkeasti jakaa ympäristöperäisiin ja eläimestä toiseen tarttuviin (Sandholm ym. 1993). Escherichia coli, Streptococcus uberis ja Actinomyces pyogenes ovat tyypillisiä ympäristöstä tulevia bakteereja, jotka elävät ja lisääntyvät lähinnä ulosteissa, kuivikkeissa ja vedessä. Tarttuvat bakteerit sen sijaan elävät ja lisääntyvät pääasiassa utareessa tai sen iholla ja leviävät helposti eläimestä toiseen. Tarttuvia utaretulehduksia aiheuttavia bakteereja ovat etenkin Staphylococcuc aureus ja Streptococcus dysgalactiae. Kaiken kaikkiaan stafylokokit ovat Suomessa merkittävimpiä utarepatogeeneja. EELAN vuonna 2001 tekemän kartoitustustutkimuksen aikana piilevistä tulehduksista noin $10 \%$ :ssa löydettiin S. aureus ja noin $50 \%$ :ssa koagulaasinegatiivisia stafylokokkeja (KNS). Lisäksi ns. lievempien utaretulehdusbakteerien, etenkin Corynebacterium bovis, osuus oli merkittävästi lisääntynyt aikaisemmista vuosista (Pitkälä 2002).

Utaretulehduksen hoidossa käytetään yleisesti antibiootteja. Lääkkeiden myyntitilastojen mukaan lypsykaudella utareen kautta annosteltavia utaretulehdusläk̈kkeitä, eli intramammaareja, myytiin vuonna 2002 noin 1,1 miljoonaa kappaletta. Tästä syystä huolestuttavaa on utaretulehdusta aiheuttavien bakteerikantojen kehittyminen antibioottilääkitykselle vastustuskykyiseksi. Tällä saattaa olla myös kansanterveydellistä merkitystä, koska antibioottien tehokkuus voi laskea myös ihmisten 
lääkinnässä. Ilmeisesti hoitojen määrän ja laajakirjoisuuden takia, utaretulehdusta aiheuttavat bakteerikannat ovat kehittyneet Suomessa antibioottilääkitykselle vastustuskykyisemmiksi kuin muissa Pohjoismaissa. Esimerkiksi puolet koagulaasinegatiivisista stafylokokeista on jo antibioottiresistenttejä (Myllys ym. 1998, Honkanen-Buzalski ja Huovinen 1999).Viime vuosina resistenttien utaretulehdusbakteerien määrä on onneksi kääntynyt hieman laskuun, vaikka penisilliiniresistenssi on edelleen etenkin S. aureus-tulehdusten ongelma (Pitkälä 2002). Useissa maissa ongelmaksi on kuitenkin muodostumassa ympäristöperäisen utaretulehduksen, kuten koliformien (yleisin E. coli) aiheuttaman mastiitin lisääntyminen, samanaikaisesti kuin tartunnallisia utaretulehduksia on onnistuttu vähentämään (esim. Erskine ym. 1988, Myllys ym. 1998, Räsänen 2000).

\section{Lehmäkohtainen bakteeritietokanta}

Soluluvun ja mastiitin välisen yhteyden tutkimuksessa on tarve määrittää soluluvun käyttäytyminen eri patogeenien aiheuttamissa infektioissa. Perinnöllinen vastustuskyky saattaa perustua erilaisiin mekanismeihin ja lehmäsukujen välillä voi olla eroa vastustuskyvyssä eri patogeeneja kohtaan. Nykyisin eläinlääkärit teettävät yhä useammin maitonäytteestä bakteeriviljelmän ennen utarehoitoohjelmaa ja lääkitystä. Nämä bakteerimääritykset tehdään joko EELAn valvomissa elintarvikelaboratorioissa tai Valion aluelaboratorioissa. Vuosittain määrityksiä tehdään noin 180000 maitonäytteestä, mutta koska näytteet yleensä ovat neljänneskohtaisia, taudinaiheuttaja saadaan selville arviolta 100000 lehmästä.

Tutkimuksen apuvälineeksi Suomeen on perustettu taudinaiheuttajatietojen tietokanta, jossa utaretulehdusten patogeenitiedot on talletettuna lehmäkohtaisesti. Tietokantaan kerättävät patogeenitiedot saadaan suoraan maitonäytteitä analysoivista laboratorioista. Patogeenitietojen keruu käynnistyi kesällä 2002. Tiedonkeruu toimii automatisoidun sähköpostin kautta. Laboratorioille on rakennettu omiin tietojärjestelmiin integroitu tietojen poimintarutiini, jonka tuloksen laboratoriot lähettävät MTT:lle. Toistaiseksi tiedonkeruu on toiminut kokeiluluontoisesti ja mukaan on pyydetty suurimpia laboratorioita.

Laboratorioista tulleiden tietojen perusteella näyttäisi, että suurin osa utaretulehdusten aiheuttajista on stafylokokkeja (Kuva 1). Tähän mennessä tiedot on saatu noin kymmestä tuhannesta maitonäytteestä ja tulokset ovat samansuuntaiset EELAN tekemän kartoitustutkimuksen kanssa. Osa tulehduksista kuitenkin on piileviä tai lieviä, jolloin tulehdus voi jäädä toteamatta tai ainakin hoitamatta. Tämän vuoksi joidenkin bakteerien yleisyys voi todellisuudessa olla hieman suurempi, kuin patogeenitietokannan perusteella näyttäisi. Yksi tällainen vähäistä tulehdusta aiheuttava patogeeni on Corynebacterium bovis, joka EELAn kartoitustutkimuksen mukaan on kohtuullisen yleinen, mutta laboratorioihin tulleista tulehdusmaitonäytteistä sitä löytyy melko harvoin.

Tietokantaan tulevia patogeenitietoja voidaan tulevaisuudessa käyttää eläinten hoidon ja eläinjalostuksen täsmentämisessä, sekä tulehduksen bakteerikohtaisen vastustuskyvyn genetiikan selvittämisessä. Soluluvun käyttäytymistä ja eläinten perinnöllistä vastustuskykyä eri bakteereille voidaan tutkia yhdistämällä terveystarkkailu- ja karjantarkkailutiedot lehmistä saataviin patogeenitietoihin. Terveystarkkailun, maidon soluluvun ja bakteeritietojen yhdistäminen antavat entistä tehokkaamman välineen utaretulehduksen terveysohjelmalle, maidon laatuohjelmalle ja kestävien eläinten valinnalle. Toisaalta patogeenitietojen perusteella voi tehdä kartoistusta patogeenitilanteesta eri puolilla Suomea ja hyödyntää tätä tietoa myös epidemiologisessa tutkimuksessa. 


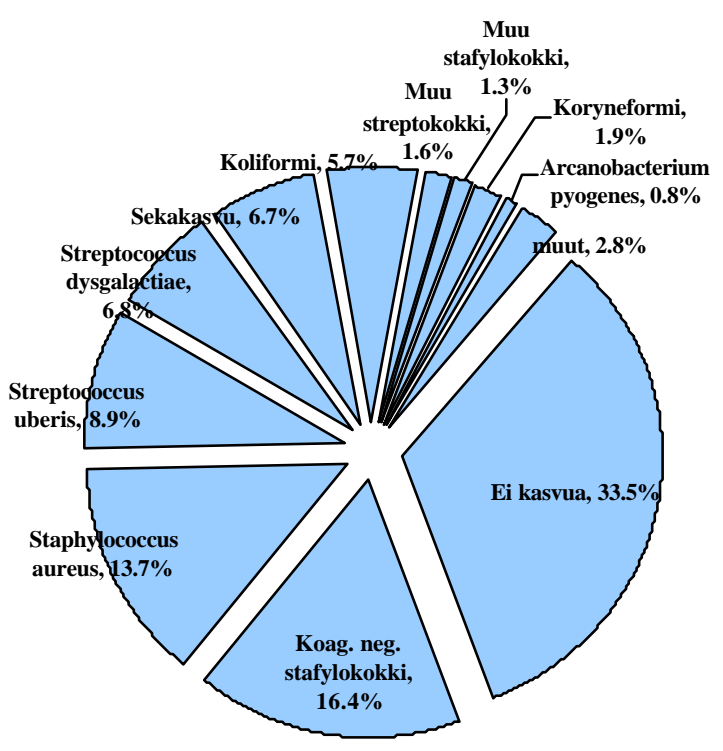

Kuva 1. Laboratorioihin lähetetyistä maitonäytteistä yleisimmin eristetyt bakteerit. Stafylokokit ovat yleisimpiä utaretulehduksen aiheuttajia (yht. 31\%) streptokokkien ollessa toiseksi tärkein patogeeniryhmä $(\mathbf{1 7 \%})$.

\section{Kirjallisuus}

Erskine, R. J., Eberhart, R. J., Hutchinson, L. J., Spencer, S. B. \& Cambell, M. A. 1998. Incidence and types of clinical mastitis in dairy herds with high and low somatic cell counts. J. Am. Vet. Med. Assoc. 192:761765.

Harmon, R. J. 1994. Symposium: Mastitis and genetic evaluation for somatic cell count. J. Dairy Sci. 77:21032112.

Heringstad, B., Klemetsdal, G. \& Ruane, J. 2000. Selection for mastitis resistance in dairy cattle: a review with focus on the situation in the Nordic countries. Livest. Prod. Sci. 64:95-106.

Honkanen-Buzalski, T. \& Huovinen, P. (toim).1999. Antibioottiresistenssi Suomessa - Finres 1999. Maa- ja metätalousministeriö ja sosiaali- ja terveysministeriö, Helsinki.

Myllys, V., Asplund, K., Brofeldt, E., Hirvelä-Koski , V., Honkanen-Buzalski, T., Junttila, J., Kulkas, L., Myllykangas, O., Niskanen, M., Saloniemi, H., Sandholm, M. \& Saranpää, T. 1998. Bovine mastitis in Finland in 1998 and 1995 - Changes in prevalence and antimicrobial resistance. Acta Vet. Scand. 39:119-126.

Persson, K., Larsson, I. \& Hallen Sandgren, C. 1993. Effects of certain inflammatory mediators on bovine neutrophil migration in vivo and in vitro. Vet. Immunol. Immunopathol. 37:99-112

Pitkälä, A. 2002. Utaretulehdus on vähentynyt. Maito ja Me 11:20-21.

Räsänen, N. 2000. Utaretulehduksen hoitokäytännöt Suomessa. Helsingin yliopisto, Eläinlääket. Tdk. Syventävät opinnot. 33s.

Sandholm, M., Honkanen-Buzalski, T., Kaartinen, L., Pyörälä, S. (toim.) 1993. Utareen sairaudet. Helsinki : Eläinlääketieteellinen Korkeakoulu. 